\title{
Dominoes: When a novel surgical approach creates new challenges
}

\author{
S. Adil Husain, MD
}

\author{
From the University of Texas Health-San Antonio, San Antonio, Tex. \\ Disclosures: Author has nothing to disclose with regard to commercial support. \\ Received for publication June 7, 2017; accepted for publication June 12, 2017; available ahead of print July 6, \\ 2017. \\ Address for reprints: S. Adil Husain, MD, University of Texas Health-San Antonio, 7703 Floyd Curl Drive/Mail \\ Code 7841, San Antonio, TX 78229 (E-mail: Husain@uthscsa.edu). \\ J Thorac Cardiovasc Surg 2017;154:e73 \\ $0022-5223 / \$ 36.00$ \\ Copyright (C) 2017 by The American Association for Thoracic Surgery \\ http://dx.doi.org/10.1016/j.jtcvs.2017.06.021
}

Initial surgical outcomes for the arterial switch operation (ASO), as reported by Jatene and colleagues, ${ }^{1}$ have an operative mortality of $20.7 \%$. Contemporary mortality data, as found in the Society of Thoracic Surgeons Congenital Heart Surgery Database, are $3.4 \% .^{2}$ Coronary anomalies, in particular those with an intramural course, continue to create technical challenges. These anomalies have been associated with a more than 6-fold increase in mortality compared with normal coronary arrangement. ${ }^{3}$

Technical strategies to navigate intramural coronary arteries have included harvesting both ostia en bloc. Although this allows for safer harvesting, removal of some portion of the facing commissure often is required. The aortocoronary flap technique has proven to be a reliable approach to produce a tension-free coronary transfer.

In the Journal, Kumar and colleagues ${ }^{4}$ from Le Bonheur Children's Hospital shared an operative strategy of using a right ventricle to pulmonary artery conduit for neopulmonary reconstruction. They suggest this technique to manage the known coronary compressive sequela seen in patients undergoing aortocoronary flap transfer. ${ }^{5}$ More specifically, they describe implantation of an aortic homograft in the pulmonary position to alleviate flap compression likely caused by patch reconstruction of the neopulmonary root after coronary harvest.

More than one half of the centers reporting to the Society of Thoracic Surgeons Congenital Heart Surgery Database perform fewer than 5 ASO procedures per year and of that nearly one half of the surgeons reporting performed individually less than 2 ASO procedures per year. ${ }^{2}$ This reality creates significant value in having a clear and wellunderstood set of technical options in cases of intramural coronary arteries. The described technique allows the surgeon to us an option, which is very commonly performed in other surgical environments, for neopulmonary reconstruction.



See Article page e69.

The authors used this technique as a bailout strategy. Clearly, a pulmonary homograft may be preferable. In addition, the suggested approach will relegate the patient to further interventions on the right ventricle outflow tract. Performing an ASO using the standard approach of coronary transfer and neo pulmonary reconstruction as a single-stage intervention is clearly ideal. The value of this manuscript is thus its introduction of a technical approach to alleviate challenges created by using a novel technical option for transfer of an intramural coronary artery.

\section{References}

1. Jatene FB, Bosisio IB, Jatene MB, Souza LC, Barbero-Marcial M, Jatene AD. Late results (50-182 months) of the Jatene operation. Eur J Cardiothorac Surg. 1992;6: $575-7$.

2. Karamlou T, Jacombs ML, Pasquali S, He X, Hill K, O’Brien S, et al. Surgeon and center volume influence on outcomes after arterial switch operation: analysis of the STS Congenital Heart Surgery Database. Ann Thorac Surg. 2014;98:904-11.

3. Pasquali SK, Hasselblad V, Li JS, Kong DF, Sanders SP. Coronary artery pattern and outcome of arterial switch operation for transposition of the great arteries. A meta-analysis. Circulation. 2002;106:2575-80.

4. Kumar TKS, Briceno-Medina M, Khan AH, Knott-Craig CJ. Right ventricle-topulmonary artery conduit for surgical management of transposition of great arteries with a complex coronary pattern. J Thorac Cardiovasc Surg. 2017; 154: e69-71.

5. Metton O, Calvaruso D, Gaudin R, Mussa S, Raisky O, Bonnet D, et al. Intramural coronary arteries and outcome of neonatal arterial switch operation. Eur J Cardiothorac Surg. 2010;37:1246-53. 